\title{
Modeling the optimal distribution of profits for risk management of oil and gas enterprises
}

\author{
Inesa Khvostina \\ Department of Applied Economics \\ Ivano-Frankivsk National Technical \\ University \\ Ivano-Frankivsk, Ukraine \\ inesa.hvostina@gmail.com
}

\author{
Viktor Oliinyk* \\ Department of Economic Cybernetics \\ Sumy State University \\ Sumy, Ukraine \\ oliynyk.viktor@gmail.com \\ Tetiana Panevnyk \\ Department of Applied Economics \\ Ivano-Frankivsk National Technical \\ University \\ Ivano-Frankivsk, Ukraine \\ panevnik.tetiana@gmail.com
}

\author{
Artem Heinrich Wiebe \\ Area Sales Manager International \\ SOLO Kleinmotoren $\mathrm{GmbH}$ \\ Sindelfingen, Germany \\ a.heinrich.wiebe@googlemail.com
}

\begin{abstract}
The article discusses the optimal management of the distribution of net profit of oil and gas enterprises in order to minimize its risks. The constructed utility function acts as a criterion of optimality. Management parameters are fractions of net profit aimed at achieving the final predicted value of the studied variables. To solve this problem, a mathematical apparatus was used, based on the theory of the Pontryagin maximum principle. As a numerical experiment, some options are proposed for optimal management of the distribution of net profit of the National Joint Stock Company Naftogaz of Ukraine for the period 2018-2022. Numerical results are given taking into account the discounting of financial flows. The proposed algorithm allows to obtain the optimal distribution of net profit within one oil and gas enterprise, which includes structural units, as well as on the scale of a group of enterprises united by one governing body that distributes financial resources for risk management.
\end{abstract}

Keywords-profit, oil and gas enterprises, optimal management, utility function, risk

\section{INTRODUCTION}

The modern system of economic relations requires significant changes in the content and forms of risk management in the activities of oil and gas enterprises. Today, the development of fuel and energy enterprises in Ukraine is in a state of uncertainty and risk. Instability of the environment negatively affects the activities of enterprises and their financial and economic situation. Insufficient attention to the issues of the influence of various factors on the production and economic activities of enterprises, the timeliness of measures for risk management leads to an inadequate reaction of individual enterprises to the dangers and threats that arise in the modern economic environment, and, as a result, the adoption of unjustified management decisions. Babenko et al. [1] consider multivariate regression models to make informed management decisions. Today, risk management measures are financed in the same amount regardless of the level of risk and the changing factors of the internal and external environment. All this contributes to the emergence of significant threats to the activities of enterprises, their limited mobility and the loss of potential opportunities. Therefore, there is a need to develop a new risk management approach based on modeling the optimal distribution of net profit to minimize risks and improve the management of oil and gas enterprises. Oliinyk \& Bielova [2] uses portfolio theory to optimize risk management of an enterprise's finances.

\section{LITERATURE REVIEW}

The strategic basis for improving the financial and economic condition and development of enterprises is strategic planning. The most important role in this is played by risk management and ensuring an adequate level of enterprise security. Problems of the theory, methodology and practice of risk management were devoted to the scientific works by domestic and foreign economists: Donecz \& Prudnikova [3], Horal \& Fadieieva [4], Shumilova \& Karataev [5], Panyagina [6], Nechaev \& Prokopyeva [7], Kaverina [8], Matviychuk et al. [9], Sudomyr [10], Shandova [11], V. Lukianova, V. Vitlinskyi, V. Lopatovskyi, A. Starostina, N. Khokhlova and other scientists. The need to create and implement a risk management mechanism is confirmed by the works: Ustenko \& Rishhuk [12], Konovalov \& Mironov [13], Sydoruk \& Baldyniuk [14], Sementsov [15], Kalashnykova [16], Khvostina et al. [17], Li [18], Mensah \& Gottwald [19], Xu [20], Rogers \& Ethridge [21], Lambrechts \& Blomquist [22], Berlin et al. [23], N. Havadzyn, N. Yurchenko. L. Neykova, T. Pakhomova, Y. Tyuleneva and other scientists. Paying tribute to the scientific excellence of scientists, it should be noted that in the economic literature does not find a proper solution complex approach to enterprise risk management. In particular, there is no defined system of distribution of financial resources taking into account different levels of risk, as well as different efficiency of investment of financial resources, taking into account the specific activity of enterprises. The scientifictheoretical and practical significance of these problems necessitates further research into risk management issues.

\section{METHODS}

The methodological basis of this study is the following scientific research methods: statistical analysis; correlation 
and regression analysis; factor analysis; simulation modeling; Pontryagin maximum principle.

\section{DISCUSSIONS AND RESULTS}

This study proposes a mathematical model of the distribution of net profit of the enterprise. The independent variables are indicators that reflect the direction of use of net profit. It is assumed that, based on historical data, one can find a regression equation for the dependence of the net profit of the enterprise $P(t)$ on these variables, namely:

$$
P(t)=a_{0}+\sum_{i=1}^{n} a_{i} X_{i}(t)
$$

where $a_{0}$ is the free term in the regression equation; $a_{i}$ regression coefficients $(i=\overline{1, n}) ; X_{i}(t)$ - independent variables $(i=\overline{1, n})$. We assume that the regression equation (1) is adequate relative to the resulting result. If the linear regression equation does not allow to obtain the desired result, then it is necessary to use a nonlinear regression equation with respect to independent variables.

For further research, it is necessary to find the distribution of independent variables for the forecast period. We assume that on the basis of historical data, the rate of change of these variables obeys some distribution law. The form of this equation depends on the numerical values obtained both on the historical period and on the final necessary result.

The task is to determine the optimal use of net profit for transferring the system from an initial state to a given final state. The utility function is the utility function of the enterprise under study. Management parameters are the shares of net profit aimed at fulfilling the task. To solve the problem of optimal management of the distribution of net profit of the enterprise, it is necessary to solve the following system.

1. The system of differential equations:

$$
\frac{d X_{i}(t)}{d t}=\mu_{i} X_{i}(t)+V_{i}(t),(i=\overline{1, n})
$$

where $\mu_{i}$ is the intensity of the change of the investigated variable $X_{i}(t) ; V_{i}(t)=v_{i} P(t)$ - management functions;

$$
v_{i} \text { - control parameters }\left(0 \leq v_{i} \leq 1, i=\overline{1, n} ; \sum_{i=1}^{n} v_{i} \leq 1\right) .
$$

2. Initial conditions :

$$
X_{i}\left(t_{0}\right)=X_{i}^{0}
$$

3. Utility function for the enterprise:

$$
\begin{aligned}
& \int_{t_{0}}^{T} \exp (-\delta t)\left\{1-\sum_{i=1}^{n} \exp \left[-v_{i}(t) P(t)\right]\right\} d t+ \\
& +\sum_{i=1}^{n} b_{i} X_{i}(T) \rightarrow \max
\end{aligned}
$$

where $b_{i}$ are the coefficients of the studied variables at a finite instant of time $T$ (obtained from the transversality condition); $\delta=\ln (1+i)$ - interest accrual rate; $i$ - interest rate (discount) $(\%)$.

As a result, we obtain a mathematical model of the optimal distribution of net profit of the enterprise. It is assumed that independent variables are transferred from a given initial state to a given final state along an optimal path relative to control parameters. To solve the resulting system (1) - (4), we use the Pontryagin maximum principle [24, 25]. The type of solution depends on the number of independent variables and the regression equation (1).

We find a solution to the problem for the case of the distribution of net profit in four directions and a linear regression equation. The main directions of using net profit: $X_{1}$ - reinvestment in assets; $X_{2}$ - deductions to reserve capital; $X_{3}$ - amount to prevent possible risks; $X_{4}-$ deduction to the State budget of Ukraine. In the model, we assume that the deduction to the State budget of Ukraine is a constant percentage of the company's net profit. In the further enumerated implementation, we will consider several possible options $(30 \%, 40 \%, 50 \%)$.

To solve this problem, we construct the Hamiltonian function:

$$
\begin{gathered}
H(t)=\sum_{i=1}^{3} \Psi_{i}(t)\left(\mu_{i} X_{i}(t)+v_{i}(t) P(t)\right)+ \\
+\exp (-\delta t)\left\{1-\sum_{i=1}^{3} \exp \left(-v_{i}(t) P(t)\right)\right\}
\end{gathered}
$$

where $P(t)=\left(1-v_{4}\right) \pi(t) ; \Psi_{i}(t)-$ auxiliary functions found from the system of differential equations (6):

$$
\begin{aligned}
& \frac{d \Psi_{j}(t)}{d t}=-\left\{\mu_{j} \Psi_{j}(t)+\right. \\
& +\left(1-v_{4}\right) a_{j}\left[\sum_{i=1}^{3} \Psi_{i}(t) v_{i}(t)+\quad,(j=\overline{1,3})\right. \\
& \left.\left.+\exp (-\delta t) \sum_{i=1}^{3} v_{i}(t) \exp \left(-v_{i}(t) P(t)\right)\right]\right\}
\end{aligned}
$$

Auxiliary functions must satisfy the transversality condition:

$$
\Psi_{i}(T)=-b_{i},(i=\overline{1,3})
$$

The optimal control parameters are:

$$
v_{i}^{*}=-\frac{\ln \left(-\Psi_{i}(t)\right)+\delta t}{P(t)},(i=\overline{1,3})
$$

As a numerical implementation of the proposed algorithm, we consider the National Joint Stock Company Naftogaz of Ukraine. We will use the results of their activities in 2018 as initial data. Consider the options for the distribution of net profit for a five-year period. To solve this problem, it is necessary to set the numerical values of the independent variables in 2022. The initial data for the calculation are presented in Table 1. 
TABLE I. DATA OF ACTIVITY OF NAFTOGAS UKRAINE, UAH MILLION

\begin{tabular}{|c|c|c|c|}
\hline & Indicators & $\mathbf{2 0 1 8}$ & $\mathbf{2 0 2 2}$ \\
\hline$\pi(t)$ & Net profit & $13613,258^{*}$ & 84129 \\
\hline$X_{1}(t)$ & Assets & $495025,674^{*}$ & 1089056 \\
\hline$X_{2}(t)$ & Allocation to reserve capital & $1960,507^{*}$ & 3034 \\
\hline$X_{3}(t)$ & Amount to prevent possible risks & 1000,000 & 3253 \\
\hline$X_{4}(t)$ & $\begin{array}{c}\text { Deduction to the State Budget of } \\
\text { Ukraine }\end{array}$ & $4083,977^{*}$ & 25238 \\
\hline \multicolumn{2}{|c|}{} & \\
\hline
\end{tabular}

Note: * - balance sheet data of NJSK Naftogaz of Ukraine, [26].

Consider several options for the optimal distribution of net profit, depending on a fixed amount of distribution to the State budget of Ukraine and the discount coefficient. For numerical implementation, we assume that the initial conditions (3) have the following form: $X_{i}(2018)=1$, ( $i=\overline{1,3}$ ). We transform the regression equation (1) to the form:

$$
\pi(t)=8,44+2,14 X_{1}-14,15 X_{2}+4,57 X_{3}
$$

Table 2 shows the optimal distribution of net profit in three directions, taking into account a discount coefficient of zero and deductions to the State budget of Ukraine of $30 \%$ of the net profit.

TABLE II. TABLE 2. DYNAMICS OF FINANCIAL FLOWS OF NAFTOGAS UKRAINE 2018-2022, $\left(\delta=0, v_{4}=0,3\right)$

\begin{tabular}{|c|l|l|l|l|l|}
\hline Indicator & $\mathbf{2 0 1 8}$ & $\mathbf{2 0 1 9}$ & $\mathbf{2 0 2 0}$ & $\mathbf{2 0 2 1}$ & \multicolumn{1}{|c|}{$\mathbf{2 0 2 2}$} \\
\hline$\pi(t)$ & 1 & 1,463 & 2,387 & 3,904 & 6,18 \\
\hline$X_{1}(t)$ & 1 & 1,136 & 1,374 & 1,726 & 2,2 \\
\hline$X_{2}(t)$ & 1 & 1,064 & 1,174 & 1,333 & 1,543 \\
\hline$X_{3}(t)$ & 1 & 1,235 & 1,667 & 2,328 & 3,253 \\
\hline
\end{tabular}

Table 3 presents the optimal share distribution of net profit in the proposed areas of use without taking into account the discount coefficient when deducting 30\%, $40 \%$ and $50 \%$ of the net profit of the enterprise to the State budget of Ukraine.

TABLE III. SHARED DISTRIBUTION OF PURE PROFIT OF NAFTOGAS UKRAINE 2018-2022, $(\delta=0)$

\begin{tabular}{|l|l|l|l|l|l|}
\hline Indicator & $\mathbf{2 0 1 8}$ & $\mathbf{2 0 1 9}$ & \multicolumn{1}{|c|}{$\mathbf{2 0 2 0}$} & $\mathbf{2 0 2 1}$ & $\mathbf{2 0 2 2}$ \\
\hline \multicolumn{5}{|l|}{$v_{4}=0,3$} \\
\hline$v_{1}(t)$ & 0 & 0,085 & 0,104 & 0,096 & 0,081 \\
\hline$v_{2}(t)$ & 0 & 0,04 & 0,05 & 0,046 & 0,039 \\
\hline$v_{3}(t)$ & 0 & 0,143 & 0,176 & 0,162 & 0,137 \\
\hline \multicolumn{5}{|l|}{$v_{4}=0,4$} \\
\hline$v_{1}(t)$ & 0 & 0,099 & 0,122 & 0,111 & 0,094 \\
\hline$v_{2}(t)$ & 0 & 0,047 & 0,059 & 0,054 & 0,046 \\
\hline$v_{3}(t)$ & 0 & 0,166 & 0,205 & 0,189 & 0,159 \\
\hline & \multicolumn{5}{|l|}{$v_{4}=0,5$} \\
\hline$v_{1}(t)$ & 0 & 0,119 & 0,146 & 0,134 & 0,113 \\
\hline$v_{2}(t)$ & 0 & 0,056 & 0,07 & 0,065 & 0,055 \\
\hline$v_{3}(t)$ & 0 & 0,2 & 0,246 & 0,226 & 0,191 \\
\hline
\end{tabular}

Table 4 shows the optimal distribution of the share distribution of net profit on the proposed variables and the trajectory of financial flows, taking into account the rate of interest and deductions to the State budget of Ukraine, 30\% of net profit.

TABLE IV. DYNAMICS OF FINANCIAL FLOWS OF NAFTOGAZ UKRAINE 2018-2022, $\left(\delta=0,05 ; v_{4}=0,3\right)$

\begin{tabular}{|c|l|l|l|l|l|}
\hline Indicator & \multicolumn{1}{|c|}{$\mathbf{2 0 1 8}$} & $\mathbf{2 0 1 9}$ & $\mathbf{2 0 2 0}$ & $\mathbf{2 0 2 1}$ & \multicolumn{1}{|c|}{$\mathbf{2 2 2}$} \\
\hline$\pi(t)$ & 1 & 0,898 & 1,64 & 3,351 & 6,18 \\
\hline$X_{1}(t)$ & 1 & 1,208 & 1,474 & 1,802 & 2,2 \\
\hline$v_{1}(t)$ & 0,134 & 0,208 & 0,146 & 0,087 & 0,056 \\
\hline$X_{2}(t)$ & 1 & 1,137 & 1,274 & 1,409 & 1,543 \\
\hline$v_{2}(t)$ & 0,136 & 0,14 & 0,071 & 0,032 & 0,016 \\
\hline$X_{3}(t)$ & 1 & 1,306 & 1,766 & 2,406 & 3,253 \\
\hline$v_{3}(t)$ & 0,126 & 0,296 & 0,247 & 0,163 & 0,111 \\
\hline
\end{tabular}

Tables 1-4 show the optimal distribution of the company's net profit for the period 2018-2022 depending on the contributions to the State Budget of Ukraine and the discount factor. An analysis of the results shows that the maximum value of deductions from net profit excluding discounting flows falls on 2020, and taking into account the discount factor falls on 2019 .

\section{CONCLUSIONS}

In this paper, we consider the problem of optimal management of the company's net profit. The distribution of net profit occurs in the most important areas of its use. One of the main areas is the use of profits to prevent possible damage from various risks. In this statement, an obligatory deduction to the State Budget of Ukraine is assumed. The optimal profit management of the enterprise is simulated, with these deductions in the amount of $30 \%, 40 \%$ or $50 \%$. Tables 2 and 3 show the distribution of net profit for the period up to 2022 without taking into account the discount factor. Table 4 shows the dynamics of financial flows and the share distribution of net profit of NJSC Naftogaz of Ukraine, taking into account the discount factor and deductions to the State budget of Ukraine in the amount of $30 \%$ of the net profit $\left(\delta=0,05 ; v_{4}=0,3\right)$.

Thus, the effective operation of oil and gas enterprises requires the use of modern approaches to risk management with the obligatory consideration of external and internal factors causing risks in the economic activities of enterprises. The solution to the problem ensures the optimal distribution of profits at oil and gas enterprises and the development of alternative risk management options in a highly dynamic environment. Continuous science-based monitoring of current processes at the enterprise, their assessment and forecasting of changes is the basis for optimizing the development of managerial decisions aimed at improving the overall performance of the oil and gas enterprise. In this regard, an integral part of modeling the optimal profit management of an enterprise is the operational monitoring of the current activity of the enterprise and risk factors. 
This mathematical model can be used as a guideline for adoption by the top management of the enterprise of a longterm plan for its development.

\section{REFERENCES}

[1] V. O. Babenko, V. O. Petuhova and A. S. Perepelitsia, "Forming of informatization strategic prospects for Ukraine in conditions of world economy globalization” ,Scientific Bulletin of Polissia, V. 1, № 2 (10), pp. 24-34, 2017. DOI:10.25140/2410-9576-2017-1-2(10)-2434.

[2] V. Oliinyk and I. Bielova, "Formation and Optimization of Various Portfolios Models on the VaR Indicator Basis", Financial and credit activity: problems of theory and practice, 2(23), pp.313-327, 2017. DOI: https://doi.org/10.18371/fcaptp.v2i23.121900.

[3] L. Donecz' and L. Prudnikova, "Risks of diversification of the economic activity of the enterprise", Problems and prospects of entrepreneurship development, 1, pp.16-20, 2011. [Online]. Available: http://nbuv.gov.ua/UJRN/piprp_2011_1 5 Accessed: 23 March 2019.

[4] L. Horal and I. Fadieieva, Finansovi aspekty innovatsiinoho rozvytku naftohazovoho kompleksu Ukrainy, Ivano-Frankivsk, 2016. [in Ukrainian]

[5] V. Shumilova and A. Karataev, "Information Model for Financial Risk Assessment", Modern problems of science and education, 5, 2012. [Online]. Available: http://www.scienceeducation.ru/ru/article/view?id=7086 Accessed 26 March 2019.

[6] A. E. Panyagina, "Overview of current risk assessment methods", Economics and management of innovative technologies, vol.3, 2014 [Online]. Available: http://www.ekonomika.snauka.ru/ 201/03/3966. Accessed on: August 4, 2019.

[7] A. Nechaev and A. Prokopyeva, "Identification and management of the enterprises innovative activity risks", Economic Annals-XXI, vol. 5-6, pp. 72-77, 2014

[8] N. O. Kaverina, "Scientific and methodological approaches to the analysis and risk assessment of innovation activities". Scientific Jornal "Science-Rise", vol. 5(3), pp. 74-75, 2014.

[9] A. Matviychuk, O. Novoseletskyy, S. Vashchaiev, H.Velykoivanenko and I. Zubenko, "Fractal analysis of the economic sustainability of enterprise”, SHS Web of Conferences 65, M3E2 201906005 (2019). https://doi.org/10.1051/shsconf/20196506005.

[10] S. Sudomyr, "Formation of an effective risk management system for socio-economic systems", Visnyk KhNAU named after V.V. Dokuchaev Series of Economic Sciences. 1, pp.149-153, 2018. doi:10.31359/2312-3427-2018-1-149.

111] N. Shandova, "The preventive analysis of risk factors of the development of industrial enterprises", Marketing and Management of Innovations, $1, \quad$ pp.317-326, 2018 http://doi.org/10.21272/mmi.2018.1-24

[12] A. Ustenko and L. Rishhuk, "Diahnostyka ryzykiv hospodarskoi diialnosti na pidpryiemstvakh naftohazovoho kompleksu", Naukovi pratsi Natsionalnoho universytetu kharchovykh tekhnolohii. [Online]. Available: http://nbuv.gov.ua/UJRN/Npnukht_2009_30_41 (2009) Accessed 23 March 2019. [in Ukrainian].
[13] Y. O. Konovalov and A. V. Mironov, "Risk management system: concept, functions, components", Innovative economy, vol. 9(47), pp. 127-132, 2013.

[14] N. L. Sydoruk and A. G. Baldyniuk, "Economic risks management system of enterprise activity". Economical sciences. [Online]. Available: http://www.rusnauka.com/17_AND_2010/Economics/ 69266.doc.htm. Accessed on: August 4, 2019.

[15] G. N. Sementsov, "Construction of the support system for decision making management of specific technological risks in the welldrilling process". International Periodic Scientific Journal "Modern engineering and innovative technologies", issue 7, part 3, pp. 21-36. 2019.

[16] K. M. Kalashnykova, "Zastosuvannia taksonomichnoho analizu dlia vyznachenia intehralnoho pokaznyka optymalnosti struktury kapitalu”. Upravlinnia rozvytkom, 2(123), pp.112-115, 2012. [in Ukrainian].

[17] I. Khvostina, N. Havadzyn and N. Yurchenko, "Manifestation of emergent properties in risk assessment of oil and gas companies". SHS Web of Conferences. 65, 08001 (2019). doi:10.1051/shsconf/20196508001.

[18] L. Li, "A Study on Enterprise Risk Management and Business Performance", Journal of Financial Risk Management ,Vol.7 No.1, pp. 123-138, 2018. DOI: 10.4236/jfrm.2018.71008.

[19] G. Mensah and W. Gottwald, Enterprise Risk Management: Factors Associated with Effective Implementation, Amsterdam: Social Science Electronic Publishing, 2016.

[20] M. Xu, "Design of Enterprise Training Model Based on Dynamic Knowledge Creation", American Journal of Industrial and Business Management, Vol.9(9), pp.1761-1771, 2019. DOI: 10.4236/ajibm.2019.99115.

[21] V. C. Rogers, and J. R. Ethridge, "Enterprise Risk Management in the Oil and Gas Industry: An Analysis of Selected Fortune 500 Oil and Gas Companies' Reaction in 2009 and 2010", American Journal of Business Education, 9(1), pp.23-30, 2016.

[22] D. Lambrechts and L. B. Blomquist, "Political-security risk in the oil and gas industry: the impact of terrorism on risk management and mitigation", Journal of Risk Research, 20 (10), 2017. https://doi.org/10.1080/13669877.2016.1153502.

[23] A. Berlin, A. I. Berlin, and L. L. P. Vrooman, "Managing Political Risk in the Oil and Gas Industries. Oil, Gas \& Energy Law Intelligence", 1(2), 2003. [Online]. Available: http://d.yimg.com/kq/groups/3862917/1676412124/name/Managing\% 20Political\%20Risk\%20in\%20the\%20Oil\%20and\%20Gas\%20Industr ies.pdf.

[24] S. M. Aseev, "On some properties of the adjoint variable in the relations of the Pontryagin maximum principle for optimal economic growth problems". Proceedings of the Steklov Institute of Mathematics, $287 \quad$ (S1), 2014. https://doi.org/10.1134/S0081543814090028.

[25] L. S. Pontryagin, V. G. Boltyanskii, R. V. Gamkrelidze and E. F. Mishchenko, The mathematical theory of optimal processes. New York-London. Intersciene Publishers John Wiley\&Sons, Inc., 1962.

[26] Balance NJSK Naftogaz of Ukraine. [Online]. Available: http://www.naftogaz.com/files/Zvity/Naftogaz-18fsConsolidated_UKR_for-publication.pdf. 